\title{
遠隔マニピュレータの作業空間構造獲得と障害物回避動作計画
}

\author{
長谷川 勉* 中 川 公 輔* 村上 剛 司*
}

\section{Collision-Free Path Planning of a Telerobotic Manipulator based on Swept Volume of Teleoperated Manipulator}

Tsutomu Hasegawa*, Kousuke Nakagawa* and Kouji Murakami*

\begin{abstract}
A new approach to collision-free path planning for a telerobotic manipulator is proposed. Using swept volume of a slave manipulator tele-operated by a human operator, on-line transition to autonomous tele-operation from master-slave manipulation is achieved without any geometric model of an environment. This feature enables wider application to unstructured environment.
\end{abstract}

Key Words: Teleoperation, Collision Avoidance, Roadmap, Swept Volume

1.はじめに

マスタスレーブ方式の遠隔操作は，危険な非整備環境で，事 前知識が何も与えられていないときに種々の作業を実施できる 唯一の方法であった。しかし, 初めての遠隔作業環境で障害物 に囲まれたスレーブアームが作業を遂行できるように，マスタ アームを注意深く操作するのはオペレータにとって非常に煩わ しく困難である．仮想現実の種々の手法を使えば，オペレータの 負担を軽隇することはできるだろうが，それでもマニピュレー 夕のすべての動作を決定しなければならない[1]. 本論文では, 遠隔スレーブマニピュレータの動作の自動計画への新しいアプ ローチを提案する。

障害物回避動作計画についてはこれまでに多くの手法が提案 されている [2] [3]. いずれの手法も環境内の障害物の幾何形状 や配置を表現した環境モデルが不可欠である。しかし，非整備 環境の信頼できる幾何モデルをコンピュータビジョンで自動生 成するのは非常に難しい．環境内の物体の表面光学的特性が金 属表面の全反射から暗黒色塗装面のほほ無反射まで極めて多様 であること，照明による影の存在，物体による隠蔽，物体の動 的位置変化など, 視覚画像処理にとって困難な状況が存在する からである.

本論文では，コンピュータビジョンで環境モデルを生成する ことをやめ，その代わりに自由空間のモデルを直接生成し，そ の自由空間モデルに基づいて遠隔マニピュレータの動作を自動 計画する手法を提案する。これは遠隔作業システムにおけるス レーブマニピュレータの動作軌跡が, 操作員の注意深い操縦に

原稿受付 2003 年 4 月 7 日

*九州大学

${ }^{*}$ Kyushu University
より環境内障害物との衝突を避けた安全軌跡になっていること に着目したものである。作業開始直後は操作員による操縦が必 要であるが, 作業が進めば動作の自動計画が可能になる，以下， 第 2 章では, 遠隔作業環境の三次元自由空間の生成原理を提案 し, 第 3 章では障害物回避動作計画手法について述べる。第 4 章では，開発された遠隔作業システムについて述べたのち，第 5 章でシミュレーション結果を示す．第 6 章は結論である.

\section{2. 三次元自由空間の再構成}

\section{1 空間再構成の原理}

マスタスレーブ方式の遠隔作業過程では, 操作員は, 映像モ ニタを通して環境内の障害物や作業対象の配置を知る. そして 作業手順を計画し, 障害物に衝突しないよう注意しながらマニ ピュレータを操緥して作業を実行する，遠隔のマニピュレータ 全体と把握運搬物体の衝突回避は, 操作員の目視によってなさ れる.この過程で, 関節角度空間におけるマニピュレー夕の動作 軌跡は, 関節エンコーダの出力から直接得ることができる. 実 空間ではマニピュレータの各部は一定の体積を占有し, さらに 動作軌跡にそって三次元の自由空間内を掃引することになる.

マスタスレーブマニピュレータで，いくつかのタスクを実行 すると, 関節空間（コンフィギュレーション空間：C-空間）に おける衝突のない軌跡の記録が蓄積される。関節空間ではそれ らは直線や曲線で構成される一次元セグメントであり, 連続領 域を覆うことはない。しかしそれらが三次元作業空間の掃引領 域に変換されると, 三次元の連続領域を覆うことになり, その 連続空間領域には元のマニピュレー夕動作軌跡と異なる新たな 軌跡の掃引空間が含まれるようになる。

マニピュレータが, 二つの類似してはいるが異なる動きを, 近 接した領域で実行したとしょう. 三次元実空間で二つの軌跡に 
沿った掃引空間の多くが重なっていたとしても，C-空間（関節 角度空間）では二つの軌跡は分離している。実空間では，これ ら二つの動作軌跡をつなぐ経路を多数発見することは容易であ るが，C-空間では経路を一つも発見できないことになる。この ことが, 関節空間での動作軌跡を実空間の掃引空間領域に変換 することの意義を説明している，三次元の掃引空間から，さら にC-空間での自由空間領域を再構成することができる.

遠隔の三次元実作業環境は，障害物に占有された空間と物体 に占有されていない自由空間とで構成されているが，本論文で 提案する手法では，操作員が目視監視しながら遠隔操縦するス レープマニピュレータにより掃引される空間領域の集合として, 自由空間が得られる。したがって，実環境でスレーブマニピュ レータを色々動かすほど, 自由空間構造がよりょく獲得される.

\section{2 空間表現と実装}

マニピュレータが掃引する空間は複雑な形状を持つので，その 境界表面形状を正確に陽に記述するのは非常に難しい。 そこで, 三次元実空間を立方体のボクセルで表現し，ボクセルの再帰分 割と階層的干渉千ェックとの組み合わせにより，掃引空間を効 率的に記述する方法を開発した。立方体のボクセルは $3 \times 3 \times 3$ に再帰的に分割され，所望の分解能を得る.

操作員が操縦した遠隔スレーブマニピュレータの動作軌跡は, 関節センサ出力を記録して得られる。この軌跡は C-空間で離散 量子化された一連の点に変換され, 各点においてマニピュレー 夕に占有されたボクセルが干渉チェック計算により得られるの で，それらが統合されて掃引空間となる。掃引空間の補空間が マニピュレータの進入できない禁止空間とみなされる，経路計 画段階でのマニピュレータの衝突チェックはこの禁止空間に拉 ける占有チェックとなる。

遠隔操作の過程で, 操作員の操縦操作によって自由空間がど の程度再構成されたかを知ることができれば有益である。この 目的で，自由空間の獲得率を導入した。これは，マニピュレータ に実際に掃引された空ボクセルの数を数え上げて得られる。マ ニピュレータの動作範囲に障害物がない場合の動作空間全体を 構成するボクセル数を数え上げることができるので，その值と 獲得率を比較することで，遠隔操縦から自律制御への移行時期 の判断の目安となるからである。

\section{3. 衝突回避動作計画}

\section{1 ロードマップの生成}

三次元実空間での自由空間の構造が記述されると, それに対 応したC-空間での構造特徴を抽出することにより，障害物回避 動作が効率的に計画できるようになる。この目的でランダム化 ロードマップ [4] を導入する。本論文で扱う三次元実空間での自 由空間は，複雑で不規則な形状をしているうえ，遠隔操作の追 加によりその領域が増加することもあるが， ランダム化ロード マップはそのまま自然に対応できる。また遠隔マニピュレータ が作業環境内で多数の異なった動きを実行して作業する場合の 動作計画に特に有効である。

ロードマップは確率的な手法で構成されたグラフ $R=(N, E)$ である.ノード $\mathrm{N}$ は, マニピュレータが衝突していないコン フィギュレーションの集合であり，エッジ $\mathrm{E}$ は $\mathrm{N}$ における二
つのノードを連結する衝突のない経路である。ロードマップの 生成では，まずランダムにコンフィギュレーション c を生成し， それが実空間で衝突していないものであれば，Nに加える。つ いで c と N に含まれる $\mathrm{n}$ との連結を試みる。 c と $\mathrm{n}$ が連結され ると衝突回避経路であるエッジ $(\mathrm{c}, \mathrm{n})$ が $\mathrm{E} に$ に加えられる. 以上 の作業を繰り返すことによりロードマップが生成される.

\section{2 衝突回避経路の探索}

マニピュレータの初期コンフィギュレーション Ic と目標コン フィギュレーション Gc が与えられると, 衝突回避経路は次の 三つのステップで計画される.

(1) Ic からロードマップ上の近傍のノード Ni までの経路を探 索する.

(2) Gc からロードマップ上の近傍のノード $\mathrm{Ng}$ までの経路を 探索する。

（3）ロードマップ上で $\mathrm{Ni}, \mathrm{Ng}$ を繋ぐ経路を計画する.

\section{4. システム構成}

提案手法の正当性と可能性を検証するため，遠隔作業システ ムを開発した。現在の実装では, 遠隔スレーブマニピュレータ と作業環境は幾何シミュレータで置き換えている．Fig. 1 はシ ステム構成を示し，以下の要素で構成されている。

(1) 遠隔操作系：Master manipulation system

操作員のための遠隔マニピュレータ操縦悍と監視用映像 提示機能を有する操作卓である. 遠隔スレーブマニピュレー 夕の先端位置姿勢を制御するための三次元マウス（位置姿 勢の 6 軸入力）とマニピュレータの動作を監視するディス プレイで構成される。

(2) 作業実行系: Tele-manipulation site

環境モデルやマニピュレータで構成されるシミュレータで 作業動作シミュレーションを行う。スレーブマニピュレータ には 7 自由度マニピュレータ（PA-10，三菱重工）を用いる。 このマニピュレータの全長は $1,365[\mathrm{~mm}]$ である. Fig. 2 に スレーブマニピュレータとその基準座標系を示す。

（3）自由空間モデル : 3D free space model

遠隔作業空間は一辺の長さが $2,000[\mathrm{~mm}]$ の立方体空間 として定義している。立方体の各辺は基準座標系軸と平行

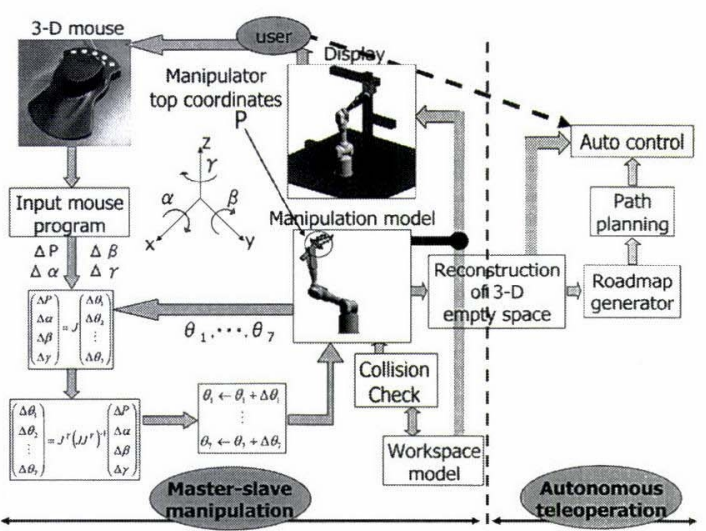

Fig. 1 System architecture 
で，その中心座標は $(300,0,1000)$ である。作業空間は再帰 的に $3 \times 3 \times 3$ のボクセルに分割され，レベル 0 の一つ の立方体からレベル 4 の 531,441 のボクセルまで階層的に 構成される。レベル 4 のボクセルの大きさは一辺の長さが 約 $25[\mathrm{~mm}]$ である.マニピュレータが実際に動作可能な 有効領域は, 環境内に何も障害物のない状態でレベル 4 の 531441 ボクセルのうち 221303 ボクセルである.

(4) ロードマップ生成系 : Randomized Roadmap generator

C-空間（関節角度空間）でランダムにコンフィギュレー ション（関節角度ベクトル）在生成する generator および， 生成されたコンフィギュレーションをその時点での作成途 中のロードマップに接続する local planner で構成される. ロードマップ生成の手続きは以下のとおりである。新しい コンフィギュレーションが生成されるたびに，ロードマップ から関節角度空間でのユークリッド距離のしきい值（80 度） 以内にあるすべてのノードが拾い出される. local planner は，各ノードに対し，新たに生成されたコンフィギュレー ションから衝突なく接続できるかどうか調べる。現在の実 装では, 接続経路は C-空間での直線に限定し, この直線上 で 2 点間距離が 10 度以下になるまで， 2 分法による干渉 チェックを繰り返している。この干渉チェックは, マニピュ レータの三次元幾何モデルと, 階層型禁止空間モデル（自 由空間モデルの補空間）との間で行う。こうして得られた すべての干渉のない経路がロードマップに加えられる.

(5) 経路計画系: Collision Free Path Planner

与えられた初期コンフィギュレーションおよび目標コン フィギュレーションのそれぞれをロードマップに連結し，つ いで，ロードマップ内でそれら連結点同士を接続する経路 の探索を行う。前者にはロードマップ生成に使用したもの と同じ local planner を用いる。後者のロードマップ内経 路探索は $\mathrm{A}$ *アルゴリズムを用いている。

なお,ソフトウエアパッケージとして，ロボットや環境の表示 には OpenGL を，また，物体パーツ間の幾何学的な干渉千ェッ 夕計算には米国ノースカロライナ大学から公開されている VCollideを使用した [5].

\section{5. シミュレーション}

まず，基本的な考えを視覚的に説明するための単純な実験を示 す. 操作員はコンフィギュレーション $\left(\theta_{1}, \theta_{2}, \theta_{3}, \theta_{4}, \theta_{5}, \theta_{6}, \theta_{7}\right)=$ $(90,-45,0,0,0,0,0)$ から $(90,0,0,0,0,0,0)$ を通り, $(90,45,0,0,0,0,0)$ までマニピュレータを線形に動かす．Fig. 3 はこのときの掃引 空間を表している.

次に作業システムに初期コンフィギュレーション $(90,-$ $45,0,0,0,0,0)$ および目標コンフィギュレーション $(90,45,0,-$ 120,0,-90,0) を与えると, オペレータによる作業では通ったこ とのない経路（Fig. 4）を自律的に計画した。このときレベル 4 の掃引空間ボクセルは約 15,000 であった。

次に, 複雑な環境下に打叮作業のシミュレーション実験を 行った. Fig. 5 はスレーブマニピュレータによる掃引空間を表 し，レベル 4 では約 67,000 ボクセルであった。このとき空間 獲得率は $30.3 \%$ （67,000 掃引空間ボクセル／221,303 動作可 能ボクセル) である。

作業システムは, 掃引空間（Fig. 5) に基づいてロードマップ を作成した。衝突のない 5,000 個のコンフィギュレーションの ランダム選択に $6.3[\mathrm{~s}]$, それらを繋ぐ 20,000 のエッジで構成さ れるロードマップ作成に $138.6[\mathrm{~s}]$ かかった。作業システムには, 中央の障害物の左手前下方をハンドの初期位置姿勢とし, 右手 前下方を目標位置姿勢として与えた。これに対し，システムが

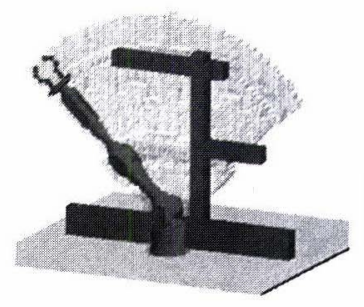

(a) Oblique view

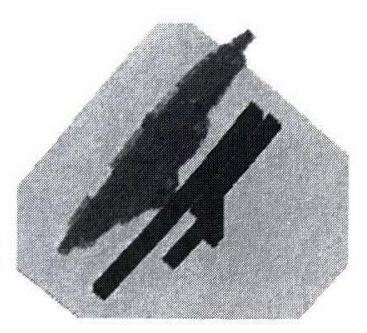

(b) Top view
Fig. 3 Swept volume (1)

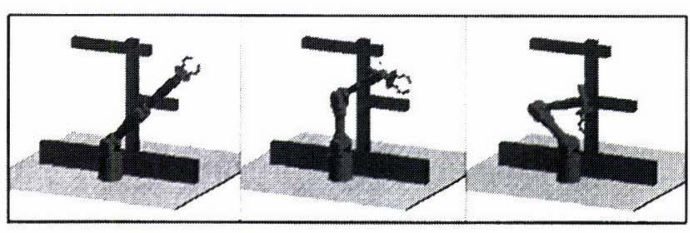

Fig. 4 New trajectory

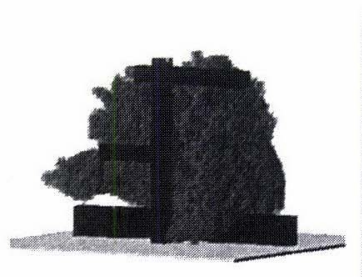

(a)

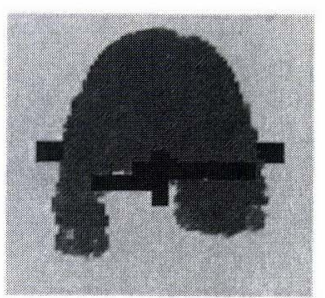

(b)
Fig. 2 PA-10 manipulator

Fig. 5 Swept volume (2) 


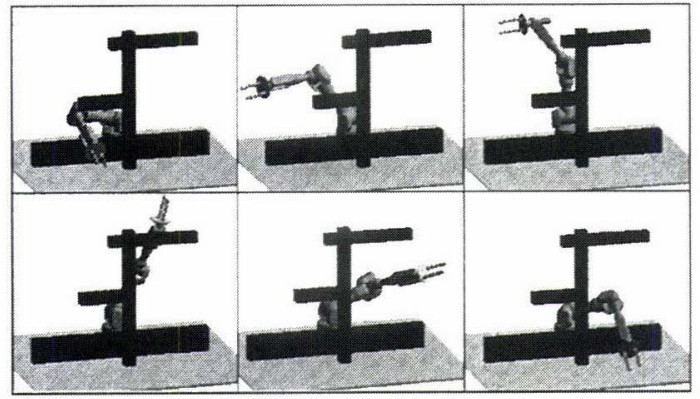

Fig. 6 Planned path (1)

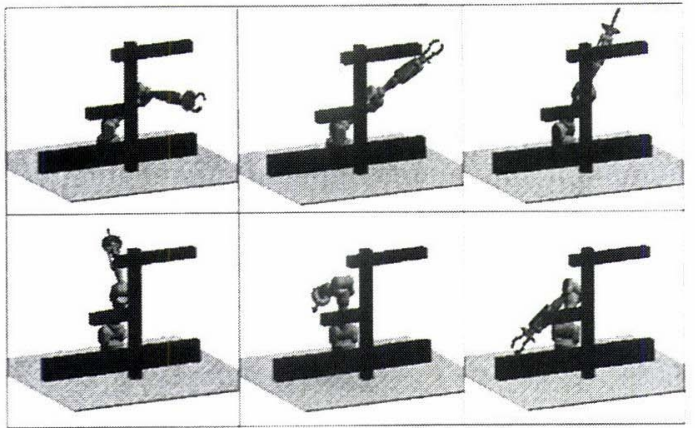

Fig. 7 Planned path (2)

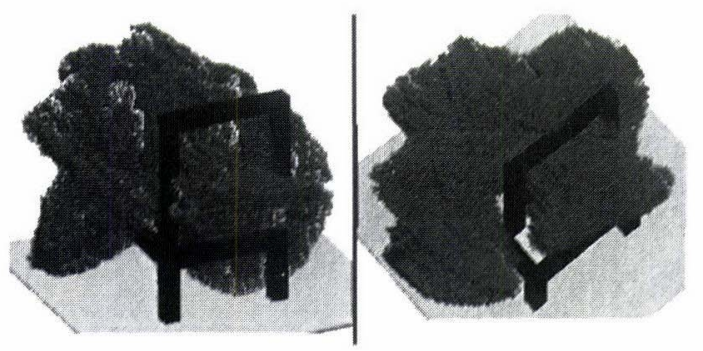

Fig. 8 Swept volume (3)

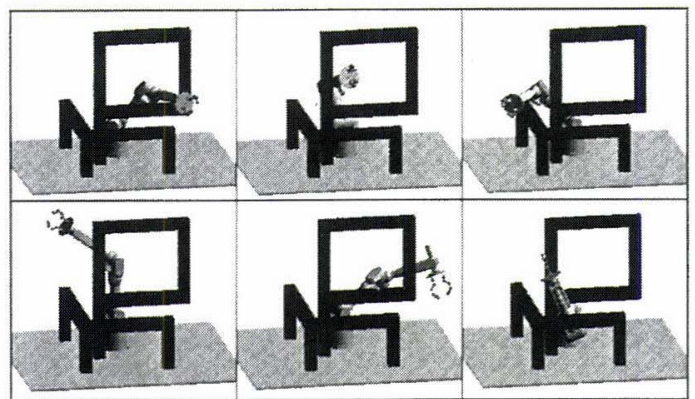

Fig. 9 Planned path (3)

計画した経路を Fig. 6 に示す．計画には $6.9[\mathrm{~s}]$ かかった．実 験は Pentium III $1 \mathrm{GHz}$ CPU を用い, 時間は 50 回の平均で ある。

Fig. 7 は計画された異なる動作を示す。また環境を変え, 操 縦操作を行って得られた掃引空間を Fig. 8 にここれに基ついて ロードマップを生成し，計画された経路の例を Fig. 9 に示す.
この例では, 図中左上のコマが表わす初期位置姿勢に対し，二 つの異なる目標位置姿勢（右上のコマと右下のコマ）を与え，そ れらを順次つなぐ経路が得られている.

\section{6. まとめと考察}

遠隔操縦されるロボットマニピュレータの掃引空間を記述す ることにより,コンピュータビジョンなしで作業環境のグロー バルな構造が獲得でき，これに基づいて自律的な障害物回避動 作計画が可能となることを明らかにした。これによりロボット を作業現場に配置したのち, 操作員の操縦により直ちに作業を 開始でき，作業環境が十分に蓄積された後には，ロボットの自 律制御に逐次移行できる見通しを得た。

本手法により可能となる応用シナリオの例として, 化学プラ ントや原子力発電プラントのような人工環境における緊急危険 作業の実施があげられる。複雑な配管中のバルブの故障修理は, その開閉, 分解, 部品交換, 再組み立てなどの夕スクが含まれ, マニピュレータはバルブ取り付け箇所近傍に何度も接近を繰り 返してそれらタスクを遂行することになる。これに対し，作業 開始当初は操作員がマニピュレータを注意深く遠隔操作するこ とになるが, 空間構造情報が蓄積された後は, 自律制御による 自動遠隔作業に切り替えることが可能になる。自律制御段階で は，視覚システムも必要となるかもしれないが，グローバルな 作業空間構造は分かっているので, 操作対象の近傍やロボット 手先周辺を監視・認識する局所的な視覚システムで十分である と考えら机る。

本提案手法は動的変化のない作業環境への応用を対象とした ものであるが, アームが移動ロボットに搭載されている場合で も, 移動動作が正確に計測できれば, アームの掃引空間が得ら れるので適用可能である。一方, 実用化システムとするうえで 解決すべき問題も残されている。

（1）動作目標とすべき手先の位置姿勢をどのように指示・指定 するか？

（2）ロボット自身の作業による環境内物体配置の変化を織り込 んで，空間記述とロードマップにどのように更新するか？ これらについては，実施すべき作業に関する事前情報，自然 言語による対話型教示，あるいは遠隔実作業環境へのレーザポ インタ [6]などが解決に役立つと思われる。

\section{参 考 文 献}

[1 ] Y. Tsumaki, M. Takahashi, W.K. Yoon and M.Uchiyama: "Virtual Rader: An Obstacle Information Display System for Teleoperation," Proc. 2002 IEEE ICRA, pp.1185-1190, 2002.

[2] J-C. Latombe: Robot Motion Planning. Kluwer, 1991.

[3] Y.K. Hwang and N. Ahuja: "Gross Motion Planning - A Survey," ACM Computing Surveys, vol.24, no.3, pp.219-291, 1992.

[4] L.E. Kavraki, P. Svestka, J-C. Latombe and M.H. Overmars: "Probabilistic Roadmaps for Path Planning in HighDimensional Configuration Spaces," IEEE Trans. RA, vol.12, no.4, pp.566-579, 1996.

[5] http://www.cs.unc.edu/ $\mathrm{dm} /$

[6] T. Hasegawa, T. Suehiro and K. Takase: "A Robot System in Unstructured Environment Based on an Environment model and Manipulation Skills," Proc. 1991 IEEE ICRA, pp.916-923, 1991 